\title{
Purification and Properties of 2-Methylcitrate Dehydratase from Yarrowia lipolytica
}

\author{
Hiroyuki AOKI and Takeshi TABUCHI \\ Institute of Applied Biochemistry, The University of Tsukuba, \\ Sakura-mura, Ibaraki 305, Japan
}

Received July 17, 1981

\begin{abstract}
2-Methylcitrate dehydratase (2-methylcitrate hydro-lyase) functioning at the methylcitric acid cycle of propionyl-CoA oxidation was purified from a cell-free extract of Yarrowia (Saccharomycopsis) lipolytica. Disc gel electrophoresis proved that the enzyme preparation was homogeneous. The molecular weight was about 79,000 in determinations by gel filtration and SDSdisc electrophoresis. The enzyme was composed of 685 residues of amino acid per molecule. The enzyme showed an isoelectric point of 3.9. No cofactor was required for full enzyme activity. The enzyme was inhibited by sulfhydryl reagents such as $p$-chloromercuribenzoate, but not by any chelating reagents. The enzyme competitively inhibited by citrate $\left(K i=4.5 \times 10^{-4} \mathrm{M}\right)$, threo- $\mathrm{D}_{\mathrm{s}}$ isocitrate $\left(K i=1.2 \times 10^{-2} \mathrm{M}\right), \quad$ threo- $\mathrm{D}_{\mathrm{s}}-2$-methylisocitrate $\left(K i=1.1 \times 10^{-3} \mathrm{M}\right)$, tricarballylate $\left(K i=3.7 \times 10^{-2} \mathrm{M}\right)$, and DL-fluorocitrate $\left(K i=9.5 \times 10^{-4} \mathrm{M}\right)$.
\end{abstract}

In a previous paper, ${ }^{1)}$ we have presented the evidence for the presence of 2-methylcitrate dehydratase (2-methylcitrate hydro-lyase), a new enzyme functioning at the methylcitric acid cycle $^{2)}$ of propionate metabolism in yeasts. The enzyme of Yarrowia (Saccharomycopsis) lipolytica catalyzes only the reversible reaction between 2 -methylcitrate (2-hydroxy-1,2,3-butanetricarboxylate) and 2methyl-cis-aconitate (cis-2-butene-1,2,3-tricarboxylate), but cannot catalyze the other reversible reaction between 2-methyl-cisaconitate and threo- $\mathrm{D}_{\mathrm{s}}-2$-methylisocitrate in the cycle. This paper described the purification and further characterization of this enzyme.

\section{MATERIALS AND METHODS}

Chemicals. 2-Methylcitrate used as a substrate was chemically synthesized by the method of Beach et al. ${ }^{3}$ threo- $\mathrm{D}_{\mathrm{s}}$-Isocitrate ${ }^{4)}$ and threo- $\mathrm{D}_{\mathrm{s}}-2$-methylisocitrate ${ }^{5)}$ were the products isolated from culture broths of $Y$. lipolytica. Molecular weight markers for gel filtration and SDS-disc electrophoresis were obtained from Boehlinger Mannheim GmbH and Daiichi Pure Chemicals Co., respectively. All other chemicals were obtained from the usual commercial sources.
Microorganism and cultivation. Saccharomycopsis lipolytica IFO 1659 was cultured by the same method described in the previous paper. ${ }^{1)}$ According to the recent proposal of van der Walt and von Arx, ${ }^{6)}$ Saccharomycopsis lipolytica is called Yarrowia lipolytica (Wickerham et al.) Comb. Nov.

Enzyme assay. The activity of 2-methylcitrate dehydratase was assayed with synthetic 2 -methylcitrate as the substrate by the same method described in the previous paper. ") The activity of aconitate hydratase [citrate (isocitrate) hydro-lyase EC 4.2.1.3] and the protein concentration were also assayed by the same method described in the previous paper. ${ }^{1)}$ One unit of activity was expressed in nanomoles per min.

Disc gel electrophoresis. Electrophoresis in a $7.5 \%$ polyacrylamide gel was carried out by the method of Davis ${ }^{7)}$ at a current of $2 \mathrm{~mA}$ for $2 \mathrm{hr}$ at $4^{\circ} \mathrm{C}$. Proteins were stained with Coomassie brilliant blue R 250 .

SDS-disc electrophoresis. SDS-disc electrophoresis was carried out by the method of Weber and Osborn ${ }^{8)}$ with a $3.3 \%$ polyacrylamide gel containing $0.1 \% \mathrm{SDS}$ at a current of $8 \mathrm{~mA}$ for $4 \mathrm{hr}$ at $25^{\circ} \mathrm{C}$ both with and without marker proteins. Proteins were stained with Coomassie brilliant blue R 250 .

Molecular weight estimation by gel filtration. Gel filtration was performed with Sephadex G-150 and G-200 columns $(2.4 \times 100 \mathrm{~cm})$ previously equilibrated with $0.05 \mathrm{M}$ phosphate buffer ( $\mathrm{pH}$ 6.5). Proteins were eluted with the 
same buffer at a flow rate of $10 \mathrm{ml}$ per hr and fractions $(5 \mathrm{ml})$ were collected.

Ultraviolet absorption. The ultraviolet absorption spectrum of the enzyme preparation was measured with a Hitachi, Model 100-50, automatic spectrophotometer.

Isoelectric focusing. Electrofocusing was carried out on a column (about $110 \mathrm{ml}$ ) containing $0.5 \%$ carrier ampholyte with $\mathrm{pH}$ ranges from $3.5 \sim 10$ and from $4 \sim 6$ (LKB) at $600 \mathrm{~V}$ for $36 \mathrm{hr}$ at $4^{\circ} \mathrm{C}$.

Amino acid composition. The purified enzyme was hydrolyzed with $6 \mathrm{~N} \mathrm{HCl}$ in a sealed, evacuated glass tube at $110^{\circ} \mathrm{C}$ for 20,40 and $70 \mathrm{hr}$. The hydrolysates were analyzed with a Durrum D-502 amino acid analyzer. Tryptophan was determined by the spectrophotometrical method of Goodwin and Morton. ${ }^{9}$ ?

Purification of the enzyme. All steps were carried out at 0 to $5^{\circ} \mathrm{C}$.

Step 1. Cell-free extract. Frozen cells $(1 \mathrm{~kg})$ were suspended in 2 liters of $0.05 \mathrm{M}$ potassium phosphate buffer (pH 6.5) containing $10 \mu \mathrm{M}$ phenylmethylsulfonyl fluoride (PMSF), and disrupted three times with a French press. After centrifugation at $10,000 \times g$ for $30 \mathrm{~min}$, the supernatant was used as a cell-free extract.

Step 2. Ammonium sulfate fractionation. Solid ammonium sulfate was added to 2 liters of the cell-free extract to $40 \%$ saturation and the mixture was allowed to stand in a refrigerator overnight. After centrifugation at $5000 \times g$ for $20 \mathrm{~min}$, solid ammonium sulfate was further added to the supernatant to $70 \%$ saturation and the mixture was allowed to stand overnight. The resulting precipitate was collected by centrifugation at $5000 \times g$ for $20 \mathrm{~min}$ and dissolved in $0.05 \mathrm{M}$ potassium phosphate buffer (pH 6.5) containing $10 \mu \mathrm{M}$ PMSF. The solution $(120 \mathrm{ml})$ was dialyzed overnight against 5 liter of the buffer described above.

Step 3. First DEAE-Sephadex A-50 chromatography. The dialyzed protein solution $(150 \mathrm{ml})$ was passed through a DEAE-Sephadex A-50 column $(6 \times 50 \mathrm{~cm})$ containing
$10 \mu \mathrm{M}$ of PMSF. The column was washed with 1 liter of the same buffer, and then eluted stepwise with each 1 liter of $0.125,0.15,0.175$ and $0.2 \mathrm{M}$ potassium phosphate

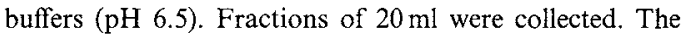
active fractions (Nos. 140 155) of 2-methylcitrate dehydratase were combined and concentrated with a collodion bag to a final volume of $20 \mathrm{ml}$.

Step 4. First Sephadex $G-200$ gel filtration. The sample from step 3 was placed on a Sephadex G-200 column $(3 \times 100 \mathrm{~cm})$ previously equilibrated with $0.05 \mathrm{M}$ potassium phosphate buffer ( $\mathrm{pH} 6.5$ ), and the enzyme was eluted with the same buffer at a flow rate of $20 \mathrm{ml}$ per $\mathrm{hr}$ and the fractions (Nos. 30 37) were combined and concentrated with the collodion bag to a final volume of $20 \mathrm{ml}$.

Step 5. Second DEAE-Sephadex A-50 chromatography. The sample from step 4 was placed on a DEAESephadex A-50 column $(3 \times 30 \mathrm{~cm})$ equilibrated with $0.1 \mathrm{M}$ potassium phosphate buffer $(\mathrm{pH} 6.5)$. The column was washed with $200 \mathrm{ml}$ of the buffer and then eluted with a gradient between 1 liter of $0.1 \mathrm{M}$ potassium phosphate buffer ( $\mathrm{pH} 6.5$ ) and 1 liter of $0.2 \mathrm{M}$ phosphate buffer at a flow rate of $20 \mathrm{ml}$ per $\mathrm{hr}$. Fractions of $8 \mathrm{ml}$ were collected. The active fractions (Nos. $41 \sim 50$ ) were combined and concentrated with the collodion bag to a final volume of $5 \mathrm{ml}$.

Step 6. Second Sephadex G-200 gel filtration. The sample from step 5 was placed on a Sephadex G-200 column $(1.8 \times 100 \mathrm{~cm})$ equilibrated with $0.05 \mathrm{M}$ potassium phosphate buffer ( $\mathrm{pH}$ 6.5) and eluted with the same buffer at a flow rate of $10 \mathrm{ml}$ per hr (Fig. 1). Active fractions were combined and concentrated to a final volume of $10 \mathrm{ml}$. The concentrated enzyme preparation was divided into $1 \mathrm{ml}$ portions containing about $15 \mathrm{mg}$ per $\mathrm{ml}$ of the enzyme and stored in liquid nitrogen. The purified enzyme was stable for over half a year under these conditions.

\section{RESULTS}

\section{Purification}

Table I shows the results of a purification run. The enzyme was purified about 200 -fold

Table I. Summary of Purification

\begin{tabular}{lccc}
\hline \multicolumn{1}{c}{ Step } & $\begin{array}{c}\text { Total } \\
\text { protein } \\
(\mathrm{mg})\end{array}$ & $\begin{array}{c}\text { Specific } \\
\text { activity }^{a}\end{array}$ & $\begin{array}{c}\text { Recovery } \\
(\%)\end{array}$ \\
\hline Cell-free extract & 140,000 & 4.8 & 100 \\
$\left(\mathrm{NH}_{4}\right)_{2} \mathrm{SO}_{4}(40 \sim 70 \%)$ & 27,500 & 20.8 & 84 \\
First DEAE-Sephadex A-50 & 6,800 & 60.6 & 61 \\
First Sephadex G-200 & 1,300 & 210 & 40 \\
Second DEAE-Sephadex A-50 & 160 & 1,050 & 25 \\
Second Sephadex G-200 & 120 & 1,080 & 19 \\
\hline
\end{tabular}

a Expressed as nanomoles per min per $\mathrm{mg}$ of protein. 


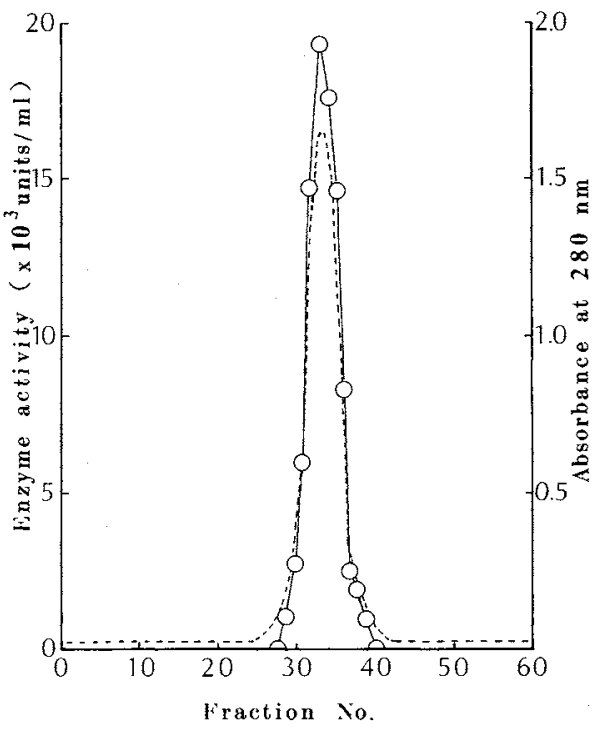

FIG. 1. Second Sephadex G-200 Column Chromatography.

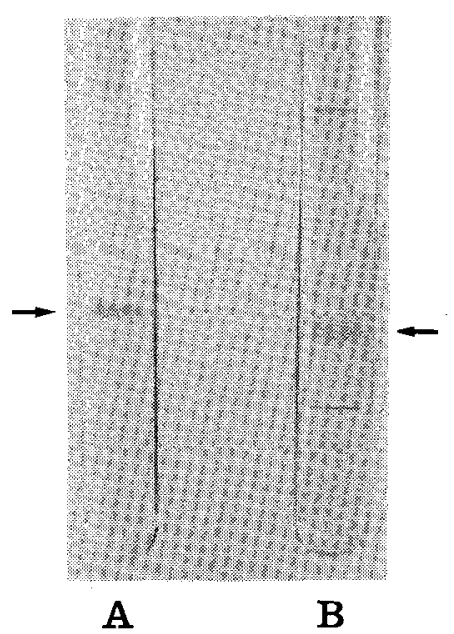

FrG. 2. Disc Gel Electrophoresis (A) and SDS-disc Electrophoresis (B) of the Purified Preparation.

from the extract with a recovery of about $20 \%$ of the original activity. In the first DEAESephadex A-50 chromatography of the purification run, the peak activity of aconitate hydratase was observed at the $0.125 \mathrm{M}$ phosphate buffer and the peak activity of 2-methylcitrate dehydratase was at the $0.15 \mathrm{M}$ phosphate buffer, respectively.

\section{Homogeneity}

As Fig. 1 shows, the chromatogram of Step

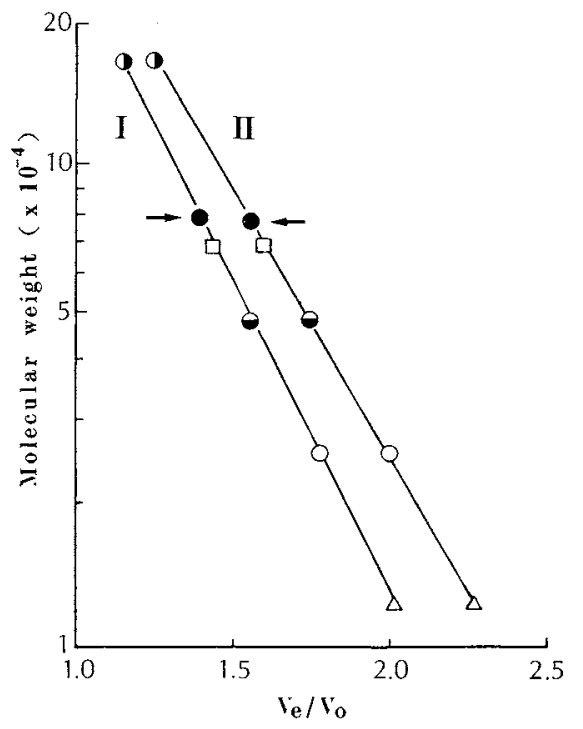

Frg. 3. Estimation of Molecular Weight by Gel Filtration on Sephadex G-150 (I) and G-200 (II).

- 2-methylcitrate dehydratase; $\triangle$, cytochrome $c ; 0$, chymotrypsinogen $A ; \ominus$, ovalbumin; $\square$, bovine serum albumin; aldolase.

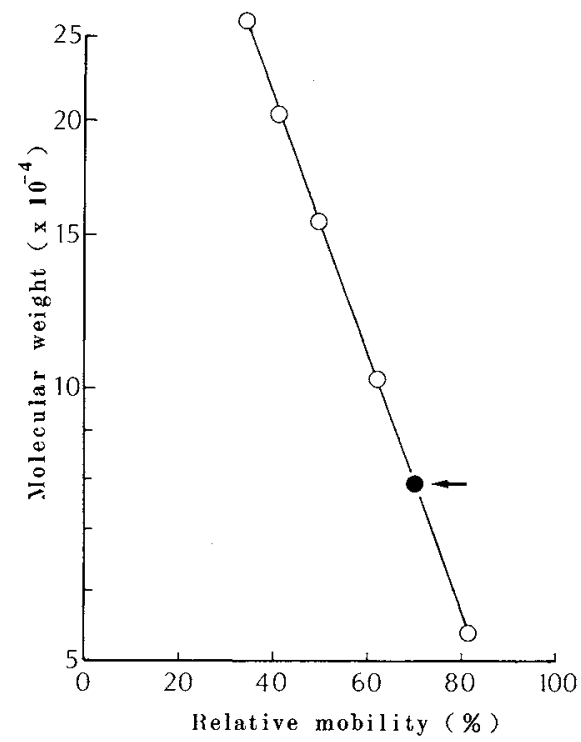

FIG. 4. Estimation of Molecular Weight by Electrophoresis on SDS-disc Acrylamide Gel.

- 2-methylcitrate dehydratase; $O$, Molecular Weight Markers-H (BDH, 53,000 265,000).

6 of the purification run showed only one protein peak. The enzyme preparation gave a single protein band both in polyacrylamide gel electrophoresis and in SDS-polyacrylamide gel 
Table II. Amino Acid Composition of 2-Methylcitrate Dehydratase

Molecular weight calculated from the total integral number of residues is 78,500 .

\begin{tabular}{lcc}
\hline Amino acid & $\begin{array}{c}\text { Residues in } \\
78,500\end{array}$ & $\begin{array}{c}\text { Residues to } \\
\text { nearest integer }\end{array}$ \\
\hline Lysine & 39.6 & 40 \\
Histidine & 12.0 & 12 \\
Arginine & 22.6 & 23 \\
Aspartate & 67.2 & 67 \\
Threonine & $36.1^{a}$ & 36 \\
Serine & $37.4^{a}$ & 37 \\
Glutamate & 58.7 & 59 \\
Proline & 26.2 & 26 \\
Glycine & 57.3 & 57 \\
Alanine & 57.3 & 57 \\
Half-cystine & $31.8^{a}$ & 32 \\
Valine & $44.6^{b}$ & 45 \\
Methionine & 2.1 & 2 \\
Isoleucine & $39.6^{b}$ & 40 \\
Leucine & 50.2 & 50 \\
Tyrosine & $17.0^{a}$ & 17 \\
Phenylalanine & 24.0 & 24 \\
Tryptophan & $60.8^{c}$ & 61 \\
Amide-NH & 13.0 & 685 \\
Total & & \\
\hline & &
\end{tabular}

a Values extrapolated to zero time of hydrolysis.

$b$ Values from $70 \mathrm{hr}$ hydrolysis.

c Determined by the method of Goodwin and Morton. ${ }^{8}$

All other values are averages of hydrolysates at 20 , 40 and $70 \mathrm{hr}$.

electrophoresis (Fig. 2).

\section{Molecular weight}

The molecular weight of 2-methylcitrate dehydratase was estimated to be 78,000 by gel filtration on Sephadex G-200, 79,000 by that on Sephadex G-150 (Fig. 3) and 79,000 by SDS-disc electrophoresis (Fig. 4). This suggests that 2-methylcitrate dehydratase has no subunit structure.

\section{Amino acid composition}

Table II shows the amino acid composition of the enzyme. The values are expressed as the number of residues per molecule assuming a molecular weight of 78,500 . The enzyme was found to consist of 685 residues of amino acid per molecule.

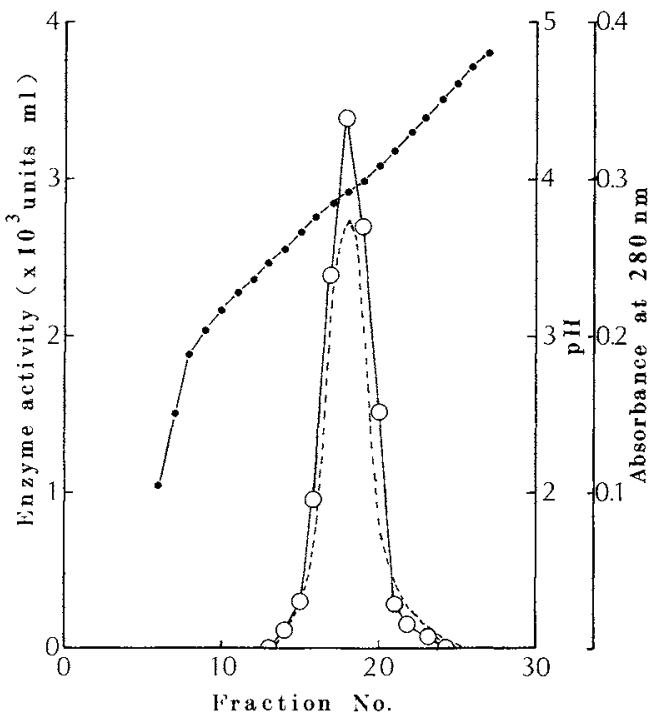

FIG. 5. Determination of Isoelectric Point of the Enzyme.

$\mathrm{O}-\mathrm{O}, 2$-methylcitrate dehydratase activity; at $4^{\circ} \mathrm{C} ;----$, absorbance at $280 \mathrm{~nm}$.

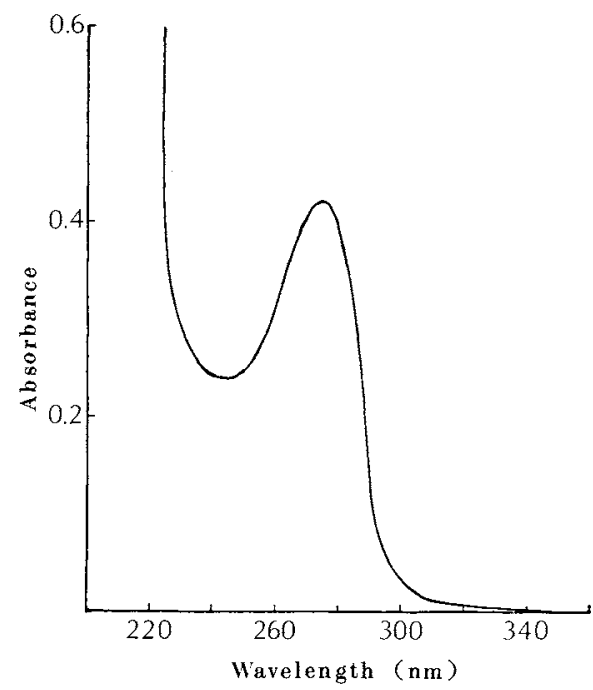

FIG. 6. Ultraviolet Absorption Spectrum.

The purified enzyme was dissolved at a concentration of $0.22 \mathrm{mg}$ per $\mathrm{ml}$ of $0.05 \mathrm{M}$ potassium phosphate buffer ( $\mathrm{pH}$ 7.0).

\section{Isoelectric focusing}

Isoelectric focusing of the enzyme preparation in an ampholyted electrofocusing column yielded a single protein peak (Fig. 5). The peak of the enzyme activity coincided with that of the protein, and the isoelectric point ( $\mathrm{p} I)$ of the 
TABLE III. EFFECT OF IONS ON ENZYME ACTIVITY

\begin{tabular}{lcc}
\hline Compound added & $(\mathrm{mM})$ & $\begin{array}{c}\text { Relative } \\
\text { activity } \\
(\%)\end{array}$ \\
\hline None & - & 100 \\
$\mathrm{NaCl}$ & 10 & 100 \\
$\mathrm{~K}_{2} \mathrm{SO}_{4}$ & 10 & 99 \\
$\left(\mathrm{NH}_{4}\right)_{2} \mathrm{SO}_{4}$ & 10 & 97 \\
$\mathrm{MgCl}_{2}$ & 10 & 93 \\
$\mathrm{CaCl}_{2}$ & 10 & 97 \\
$\mathrm{MnSO}_{4}$ & 2 & 100 \\
$\mathrm{FeSO}_{4}$ & 0.5 & 97 \\
$\mathrm{FeCl}_{3}$ & 0.5 & 98 \\
$\mathrm{CoCl}_{2}$ & 0.5 & 100 \\
$\mathrm{NiCl}_{2}$ & 0.5 & 30 \\
$\mathrm{CuSO}_{4}$ & 0.5 & 65 \\
$\mathrm{ZnCl}_{2}$ & 0.5 & 96 \\
$\left.\mathrm{Hg}_{2} \mathrm{NO}_{3}\right)_{2}$ & 0.5 & 38 \\
$\mathrm{PbCl}_{2}$ & 0.5 & 40 \\
\hline
\end{tabular}

Table IV. Effects of Various Reagents ON ENZYME ACTIVITY

\begin{tabular}{lcc}
\hline \multicolumn{1}{c}{ Compound added } & $(\mathrm{mM})$ & $\begin{array}{c}\text { Relative } \\
\text { activity } \\
(\%)\end{array}$ \\
\hline None & - & 100 \\
Phenylmethylsulfonyl fluoride & 0.1 & 99 \\
Dithiothreitol & 20 & 99 \\
2-Mercaptoethanol & 20 & 98 \\
Cysteine & 20 & 100 \\
p-Chloromercuribenzoate & 1 & 9 \\
Iodoacetate & 1 & 13 \\
EDTA & 10 & 100 \\
o-Phenanthroline & 10 & 99 \\
2,2'-Dipyridyl & 10 & 100 \\
\hline
\end{tabular}

enzyme was estimated to be 3.9 .

\section{Ultraviolet absorption spectrum}

Figure 6 shows the ultraviolet absorption spectrum of the enzyme in $0.05 \mathrm{M}$ potassium phosphate buffer ( $\mathrm{pH}$ 7.0). A peak was observed at $275 \mathrm{~nm}$. No visible absorption was observed. The extinction coefficient $\left(E_{1 \mathrm{~cm}}^{1 \%}\right)$ of this enzyme at $280 \mathrm{~nm}$ was calculated to be 24.3.

\section{Effect of various ions}

Table III shows the effect of various ions on enzyme activity. No stimulation of enzyme
Table V. EFfects of Metabolites and Analogs on Enzyme Activity

\begin{tabular}{|c|c|c|}
\hline Compound added & $(\mathrm{mM})$ & $\begin{array}{c}\text { Relative } \\
\text { activity } \\
(\%)\end{array}$ \\
\hline None & - & 100 \\
\hline Citrate & 2.5 & 62 \\
\hline DL-Fluorocitrate & 5.0 & 68 \\
\hline threo- $\mathrm{D}_{\mathrm{s}}$-Isocitrate & 2.5 & 91 \\
\hline threo-DL-Isocitrate & 5.0 & 92 \\
\hline cis-Aconitate & 2.5 & 60 \\
\hline trans-Aconitate & 2.5 & 98 \\
\hline threo- $\mathrm{D}_{\mathrm{s}}-2-\mathrm{Methylisocitrate}$ & 2.5 & 78 \\
\hline Tricarballylate & 2.5 & 93 \\
\hline Pyruvate & 2.5 & 97 \\
\hline Oxaloacetate & 2.5 & 98 \\
\hline 2-Oxoglutarate & 2.5 & 99 \\
\hline Succinate & 2.5 & 98 \\
\hline Fumarate & 2.5 & 98 \\
\hline DL-Malate & 5.0 & 100 \\
\hline Malonate & 2.5 & 99 \\
\hline Adipate & 2.5 & 100 \\
\hline Glutarate & 2.5 & 98 \\
\hline L-Glutamate & 2.5 & 99 \\
\hline L-Aspartate & 2.5 & 98 \\
\hline
\end{tabular}

activity by any ion was observed under the experimental conditions, although several bivalent metal ions, such as nickel, copper, zinc, mercury, and lead, inhibited the activity to some extent.

\section{Effects of various reagents and metabolites}

The effects of various reagents and structural analogs on enzyme activity were examined. For measuring inhibition or stimulation, the enzyme was first incubated for $10 \mathrm{~min}$ at $25^{\circ} \mathrm{C}$ with the test compound in the assay mixture minus the substrate. The reaction was then started by adding the substrate and enzyme activity was assayed.

As Table IV shows, phenylmethylsulfonyl fluoride, an inhibitor of protease, had no effect on enzyme activity and so it was added in the buffer used in the early steps of purification. Sulfhydryl compounds such as dithiothreitol or mercaptoethanol had no observable effect on enzyme activity. The enzyme was strongly inhibited by sulfhydryl binding reagents such as $p$-chloromercuribenzoate and iodoacetate, 


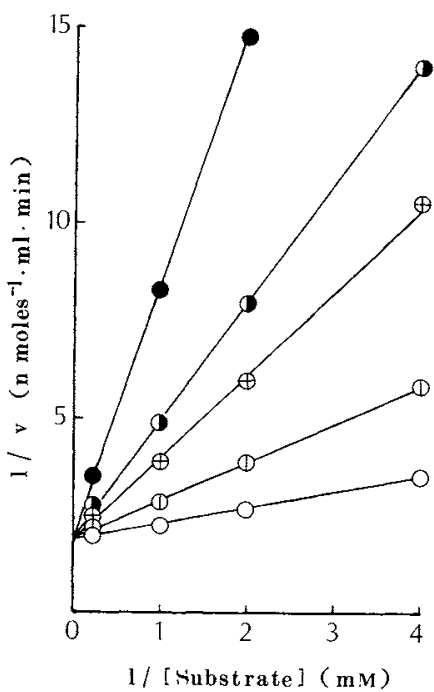

FIG. 7. Competitive Inhibition of 2-Methylcitrate Dehydratase by Citrate.

The concentration of citrate added: $\bigcirc$, none; $\mathbb{D}, 0.1 \mathrm{~mm}$; $\oplus, 0.5 \mathrm{~mm} ; 1.0 \mathrm{~mm} ; 2.5 \mathrm{~mm}$.

as well as by the ions of copper, silver, mercury, and lead, as already shown in Table III. However, no chelating reagents showed any effect on enzyme activity.

Table $\mathrm{V}$ shows the effect of metabolites and structural analogs on enzyme activity. The enzyme was inhibited by several structural analogs such as citrate, cis-aconitate, isocitrate, 2-methylisocitrate, tricarballylate and fluorocitrate, but not by trans-aconitate ${ }^{10)}$ or adipate $^{11)}$ known as the inhibitors of aconitate hydratase.

\section{Effects of adenylates and coenzymes}

For the evaluation of the regulatory function of this enzyme, the effects of certain adenylate compounds and coenzymes on enzyme activity were examined. The following compounds tested at a concentration of $1 \mathrm{~mm}$ had no effect on enzyme activity: AMP, ADP, ATP or NAD $(P)(H)$. Pyruvate, the end product of the cycle, also had no effect on enzyme activity (Table V).

\section{Kinetics}

The rate of substrate conversion by the enzyme followed the standard Michaelis-
Menten kinetics curve. The apparent $K m$ value for the synthetic 2-methylcitrate consisting of the two racemic pairs of diastereoisomers was calculated to $1.9 \times 10^{-4} \mathrm{M}$ from LineweaverBurk plots.

As Fig. 7 shows, citrate competitively inhibited enzyme activity $\left(K i=4.5 \times 10^{-4} \mathrm{M}\right)$. Competitive inhibition was also observed with the other structural analogs: threo- $\mathrm{D}_{\mathrm{s}}$ isocitrate $\left(K i=1.1 \times 10^{-2} \mathrm{M}\right), \quad$ threo $-\mathrm{D}_{\mathrm{s}}-2$ methylisocitrate $\left(K i=1.2 \times 10^{-3} \mathrm{M}\right), \quad$ DLfluorocitrate $\left(K i=9.5 \times 10^{-4} \mathrm{M}\right)$ and tricarballylate $\left(K i=3.7 \times 10^{-2} \mathrm{M}\right)$.

\section{DISCUSSION}

We have previously shown that 2-methylcitrate dehydratase is highly specific for substrates and has no activity on threo- $\mathrm{D}_{\mathrm{s}}-2$ methylisocitrate or the substrate of aconitate hydratase, namely, citrate, cis-aconitate or threo- $\mathrm{D}_{\mathrm{s}}$-isocitrate. ${ }^{1)}$ The present experiments show that threo- $\mathrm{D}_{\mathrm{s}}-2$-methylisocitrate, citrate and threo- $\mathrm{D}_{\mathrm{s}}$-isocitrate are competitive inhibitors of this enzyme.

Differing from aconitate hydratase, 2methylcitrate dehydratase was not stimulated by ferrous ions or by sulfhydryl compounds and was not inhibited by trans-aconitate or any of chelating reagents. The enzyme showed a $\mathrm{p} I$ value (3.9) close to that (4.2) of the aconitate hydratase of $Y$. lipolytica, ${ }^{12)}$ but did no visible absorption. 2-Methylcitrate dehydratase appears to be monomeric, and its molecular weight $(78,500)$ is larger than that $(68,500)$ of the aconitate hydratase of the same strain of $Y$. lipolytica. ${ }^{12)}$ The amino acid composition of the enzyme clearly differed from that of the aconitate hydratase described by Suzuki et al. ${ }^{13)}$ These results also show that 2 methylcitrate dehydratase differs from the apoenzyme of aconitate hydratase. ${ }^{14)}$

We have shown in a previous study that the methylcitric acid cycle enzymes are constitutive and the degree of glucose repression in the enzymes is similar to glucose repression in several enzymes of the citric acid cycle in $Y$. lipolytica, ${ }^{1,15)} 2$-Methylcitrate synthase func- 
tioning at the start of the cycle has been shown to be inhibited by $\mathrm{NAD}(\mathrm{P}) \mathrm{H}$ and ATP. ${ }^{16)}$ 2-Methylisocitrate lyase yielding pyruvate, the end product of the cycle, has been shown to be also inhibited by $\mathrm{NAD}(\mathrm{P}) \mathrm{H}$ but activated by NAD. ${ }^{17)}$ However, the present experimental results show that 2-methylcitrate dehydratase was not affected by any of the adenylate compounds or coenzymes. This suggests that 2-methylcitrate dehydratase does not have the mechanism of fine control in enzyme activity.

Acknowledgments. We thank Dr. H. Uchiyama and Dr. T. Nakahara of our institute for their interest and helpful suggestions. This work was partly supported by a Grant-in-Aid for Scientific Research (No. 556066, 1980) from the Ministry of Education, Science and Culture of Japan.

\section{REFERENCES}

1) T. Tabuchi, H. Aoki, H. Uchiyama and T. Nakahara, Agric. Biol. Chem., 45, 2823 (1981).

2) T. Tabuchi, N. Serizawa and H. Uchiyama, Agric. Biol. Chem., 38, 2571 (1974).
3) R. L. Beach, T. Aogaichi and G. W. E. Plaut, J. Biol. Chem., 252, 2702 (1977).

4) M. Abe and T. Tabuchi, Agric. Biol. Chem., 32, 392 (1968).

5) T. Tabuchi and S. Hara, Agric. Biol. Chem., 38, 1105 (1974).

6) J. P. van der Walt and J. A. von Arx, Antonie van Leeuwenhoek, 46, 517 (1980).

7) B. J. Davis, Ann. N. Y. Acad. Sci., 121, 404 (1967).

8) K. Weber and M. Osborn, J. Biol. Chem., 244, 4406 (1969).

9) T. W. Goodwin and R. A. Morton, Biochem. J., 40, 628 (1946).

10) J. J. Villafranca, J. Biol. Chem., 249, 6149 (1974).

11) B. Treton and H. Heslot, Agric. Biol. Chem., 42, 1201 (1978).

12) T. Suzuki, O. Yamazaki, K. Nara, S. Akiyama, Y. Nakao and H. Fukuda, J. Biochem., 77, 367 (1975).

13) T. Suzuki, S. Akiyama, S. Fujimoto, M. Ishikawa, Y. Nakao and H. Fukuda, J. Biochem., 80, 799 (1976).

14) T. Suzuki, S. Akiyama, S. Fujimoto, M. Ishikawa, Y. Nakao and H. Fukuda, J. Biochem., 80, 805 (1976).

15) T. Tabuchi and K. Igoshi, Agric. Biol. Chem., 42, 2381 (1978).

16) H. Uchiyama and T. Tabuchi, Agric. Biol. Chem., 40, 1411 (1976).

17) T. Tabuchi and T. Satoh, Agric. Biol. Chem., 41, 169 (1977). 